\title{
Biodeterioration of majolica glazed tiles by the fungus Devriesia imbrexigena
}

\author{
M.L. Coutinho ${ }^{\mathrm{a}, \mathrm{b}, *}$, A.Z. Miller ${ }^{\mathrm{b}, \mathrm{c}}$, A. Phillip ${ }^{\mathrm{d}}$, J. Mirão ${ }^{\mathrm{b}}$, L. Dias ${ }^{\mathrm{b}}$, M.A. Rogerio-Candelera ${ }^{\mathrm{c}}$, C. Saiz-Jimenez $^{\mathrm{c}}$, \\ P.M. Martin-Sanchez ${ }^{\mathrm{e}, \mathrm{f}}$, L. Cerqueira-Alves ${ }^{\mathrm{g}}$, M.F. Macedo ${ }^{\mathrm{a}}$ \\ ${ }^{a}$ VICARTE, Research Unit Vidro e Cerâmica para as Artes, Faculdade de Ciências e Tecnologia, Universidade Nova de Lisboa, Campus Caparica, 2829-516 Caparica, Portugal \\ ${ }^{\mathrm{b}}$ Laboratório HÉRCULES, Universidade de Évora, Largo Marquês de Marialva, 8, 7000-554 Évora, Portugal \\ ' Instituto de Recursos Naturales y Agrobiologia de Sevilla, IRNAS-CSIC, Av. Reina Mercedes 10, 41012 Sevilla, Spain \\ ${ }^{\mathrm{d}}$ University of Lisbon, Faculty of Sciences, Biosystems and Integrative Sciences Institute (BioISI), Campo Grande, 1749-016 Lisbon, Portugal \\ ${ }^{\mathrm{e}}$ Section for Genetics and Evolutionary Biology (Evogene), Department of Biosciences, University of Oslo, P.O. Box 1066 Blindern, NO-0316 Oslo, Norway \\ ${ }^{\mathrm{f}}$ Bundesanstalt für Materialforschung und -prüfung (BAM), Department 4 (Materials and Environment), Unter den Eichen 87, 12205 Berlin, Germany \\ ${ }^{\mathrm{g}}$ C2TN, Instituto Superior Técnico, Universidade de Lisboa, Portugal
}

\section{H I G H L I G H T S}

- Fungal bioreceptivity and biodeterioration of historical glazed tiles models was studied.

- Tile models with two different ageing degrees (pristine and artificially aged) were tested.

-12-month laboratory colonization experiment was conducted with the tiles inoculated with fungi.

- Biogenic calcium oxalate compounds were formed due to fungal biodeterioration.

- Bioreceptivity and biodeterioration was not correlated with ageing degree.

\section{A R T I C L E I N F O}

\section{Article history:}

Received 25 May 2018

Received in revised form 28 February 2019

Accepted 21 March 2019

Available online 1 April 2019

\section{Keywords:}

Glazed tiles

Bioreceptivity

Biodeterioration

Fungi

Ceramic

\begin{abstract}
A B S T R A C T
This study aimed at evaluating the influence of ageing on the bioreceptivity and biodeterioration of glazed tiles by fungi. These microorganisms have been identified in historical tile colonizing microbial communities. A 12-month laboratory colonization experiment was conducted using pristine and artificially aged tile models inoculated with Devriesia imbrexigena. Fungal growth was evaluated by digital image analysis after incubation. Scanning electron microscopy and micro-Raman spectroscopy were performed to assess tile biodeterioration, revealing that organic acids exuded by $D$. imbrexigena induced the precipitation of calcium oxalate on the glazed surfaces. Results also showed that the ageing degree was not related to bioreceptivity.
\end{abstract}

() 2019 Elsevier Ltd. All rights reserved.

\section{Introduction}

Glazed tiles are ceramic building materials with high artistic and cultural value due to the variety of colours, glosses and iconography of these ceramic elements, which are responsible for the uniqueness of buildings and the urban landscape of many countries worldwide [1]. These composite materials combine a layer of porous ceramic material (ceramic body) with a vitreous coating (glaze) [2]. When exposed outdoors, these cultural assets are subjected to weathering and also to the development of biological

\footnotetext{
* Corresponding author.

E-mail address: mathildal@gmail.com (M.L. Coutinho).
}

patinas on their surfaces which can lead to undesirable alterations, designated as biodeterioration [3]. On ceramic materials the main biological damage are caused by: (i) aesthetic biodeterioration due to the production of organic pigments and coverage of the surface by coloured biofilms; (ii) physical biodeterioration resulting from mechanical forces produced by organisms within pores, cracks, fissures and ceramic-glaze interface causing material disintegration, and (iii) chemical biodeterioration due to the direct action of metabolic products excreted by microorganisms [4].

Recent studies identified meristematic fungi in microbial communities growing over glazed tiles [5-7]. For instance, Giacomucci et al. [5] found Aureobasidium pullulans and uncultured Dothioraceae among other fungal species on the adhesive treated glazed 
wall tiles in Venice (Italy). Moreover, two distinct case studies regarding Portuguese glazed tiles identified members of the Neodevreodiseae family on the tile colonizing microbial community $[6,8]$. Black yeasts and meristematic fungi are able to survive in adverse environmental conditions, such as low humidity and high sun irradiation [9]. Their survival strategy through melanin production and meristematic development make them apt to develop and colonize inorganic substrates in hostile conditions [9].

Most of the studies regarding biodeterioration of glazed tiles have focused on the identification of the colonizing microorganisms $[5,8,10,11]$. However, laboratory-based inoculation experiments are fundamental to understand biodeterioration processes and to relate material properties with susceptibility to microbial colonization [12]. Fungi are responsible for the decay of many types of building materials [13-15]. Laboratory tests on unglazed ceramic roof tiles have shown that fungi are able to form bioprecipitates and penetrate into pores affecting the material integrity $[16,17]$. In addition, several studies focused on stained glass windows from cultural heritage assets [18-20] and laboratory-based colonization experiments $[14,15,21,22]$ have provided important insights into glass biodeterioration by fungi, showing that they able to cause glass biocorrosion. Yet, studies on the biodeterioration of glazed tiles have mainly focused on the identification of colonizing microorganisms $[4-6,8,10]$ and no laboratory experiments have been performed on fungal biodeterioration of historical glazed ceramic tiles.

In the field of cultural heritage, understanding how the ageing degree and conservation condition have an effect on the vulnerability to a certain deterioration form is crucial in order to be able to prioritise and design proper preventive and curative treatments. In this study, a laboratory-based colonization experiment was carried out using newly produced tile models with two different ageing degrees: (i) pristine (without ageing) and (ii) with artificial ageing (aged). These tiles were inoculated with $D$. imbrexigena and incubated for 12 months to assess their biodeterioration under laboratory conditions. The species Devriesia imbrexigena, Phillips \& Coutinho, a novel dematiaceous fungus described on majolica glaze tiles from Pena National Palace [23] was selected for its ability to grow on glazed tiles. At the end of the incubation period, fungal growth was evaluated by digital image analysis. Biodeterioration damage was assessed by optical microscopy (OM), scanning electron microscopy (SEM) and micro-Raman spectroscopy ( $\mu$-Raman).

\section{Materials and methods}

\subsection{Pristine and aged majolica glazed tile models}

Thirty eight glazed tile models (approximately $2.5 \times 2.5 \mathrm{~cm}$ ) were produced in the laboratory according to the manufacturing procedure of majolica ceramic tiles, using a faience ceramic paste and a silica lead-alkali glaze opacified with tin [24]. The produced tile models were divided into two sets of tile samples: (i) 19 newly produced tiles without ageing (hereinafter pristine) and (ii) 19 newly produced tiles with artificial ageing (hereinafter aged). The aged tiles were obtained by submitting the produced tiles to a thermal shock treatment and chemical corrosion as described in a previous work [24]. The average chemical composition of the glaze surface of the pristine and aged tiles before ( $\mathrm{Bf})$ the inoculation experiment is presented in Table 1 [24].

The main intrinsic physical features of the pristine and aged tile models before the inoculation experiment, including water absorption by capillarity of the glazed surface, water vapor permeability and surface roughness (Ra) are summarized in Table 2 [24].

\subsection{Laboratory-based tile biodeterioration experiment}

The two sets of tile samples, pristine (16 replicates) and aged (16 replicates), were placed separately inside two Petri dishes $(\varnothing=9 \mathrm{~cm})$. A third Petri dish was used for control samples (without inoculation) containing three pristine tile models (hereinafter pristine control) and three aged tile models (hereinafter aged control). Prior to the inoculation, all the Petri dishes containing the tile models were steril-
Table 1

Chemical composition (wt. \%) of the glaze analyzed by $\mu$-PIXE in pristine ( $\mathrm{n}=3$ ) and aged $(n=3)$ tile model samples before inoculation $(B f)$. Mean values are presented together with the standard deviation (SD) and ANOVA results [24].

\begin{tabular}{lll}
\hline Oxides $($ wt. \%) & pristine $(\mathrm{Bf})($ mean $\pm \mathrm{SD})$ & Aged $(\mathrm{Bf})($ mean $\pm \mathrm{SD})$ \\
\hline $\mathrm{Na}_{2} \mathrm{O}$ & $0.3 \pm 0.04$ & $0.3 \pm 0.06$ \\
$\mathrm{MgO}$ & $0.4 \pm 0.03$ & $0.4 \pm 0.01$ \\
$\mathrm{Al}_{2} \mathrm{O}_{3}$ & $3.4 \pm 0.30$ & $3.2 \pm 0.10$ \\
$\mathrm{SiO}_{2}$ & $47.0 \pm 2.70$ & $45.2 \pm 5.20$ \\
$\mathrm{Cl}$ & $0.1 \pm 0.05$ & $0.1 \pm 0.10$ \\
$\mathrm{~K}_{2} \mathrm{O}$ & $1.5 \pm 0.10$ & $1.3 \pm 0.01$ \\
$\mathrm{CaO}$ & $1.0 \pm 0.08$ & $1.1 \pm 0.10$ \\
$\mathrm{TiO}_{2}$ & $0.1 \pm 0.02$ & $0.1 \pm 0.01$ \\
$\mathrm{Fe}_{2} \mathrm{O}_{3}$ & $0.2 \pm 0.01$ & $0.2 \pm 0.03$ \\
$\mathrm{SnO}_{2}$ & $10.2 \pm 0.10$ & $10.0 \pm 1.00$ \\
$\mathrm{PbO}$ & $35.7 \pm 2.50$ & $38.0 \pm 4.50$ \\
\hline
\end{tabular}

Values in the same row were not significantly different by the Tukey HDS test at $\mathrm{p}<0.05$.

\section{Table 2}

Average and standard deviation $( \pm S D)$ of capillarity coefficient $(Q)$, water vapour permeability coefficient $(\delta)$ and average roughness (Ra) of pristine $(n=3)$ and aged $(n=3)$ tile model samples before (Bf) the laboratory-based colonization experiment [24].

\begin{tabular}{llll}
\hline Model tile & $\mathrm{Q}\left(\mathrm{g} \mathrm{m}^{-2} \mathrm{~s}^{-1 / 2}\right)$ & $\delta(\mathrm{kg} / \mathrm{m} \mathrm{h} \mathrm{Pa})$ & $\mathrm{Ra}(\AA)$ \\
\hline pristine $(\mathrm{Bf})$ & $1.3 \pm 1.4(\mathrm{a})$ & $1.5 \times 10^{-10} \pm 4.6 \times 10^{-11}(\mathrm{a})$ & $12.6 \pm 3.2(\mathrm{a})$ \\
aged (Bf) & $10.8 \pm 6.1(\mathrm{a})$ & $3.9 \times 10^{-10} \pm 1.3 \times 10^{-10}(\mathrm{~b})$ & $13.0 \pm 1.4(\mathrm{a})$ \\
\hline
\end{tabular}

Values followed by the same letters in brackets in the same column are not significantly different by the Tukey HDS test at $\mathrm{p}<0.05$.

ized (at $121^{\circ} \mathrm{C}, 100 \mathrm{kPa}$ above atmospheric pressure, $\mathrm{t}=20 \mathrm{~min}$ ). An axenic culture of the fungus $D$. imbrexigena, previously isolated from historic glazed tiles [23], was grown in half-strength PDA (Scharlau, Spain) plates at room temperature. For preparing the inoculum, fungal biomass was scraped from the PDA plates with a sterile scalpel and suspended in diluted potato dextrose broth $(2 \%, 2 \mathrm{~g} / 100 \mathrm{~mL})$ (Scharlau, Spain). The number of fungal units (conidia) per $\mathrm{ml}$ was determined through direct microscopic counts by using a haemocytometer and adjusted at a concentration of $10^{5}$ cells $/ \mathrm{mL}$. Subsequently, $150 \mu \mathrm{l}$ of fungal suspension were inoculated onto the centre of the depression of the glazed surface of the tile models Every 3 months, the tile samples were re-inoculated with $150 \mu \mathrm{l}$ of freshly prepared fungal suspension to simulate reposition of cells naturally occurring outdoors. All tile samples (inoculated and control samples) were kept under the same conditions (22-23 ${ }^{\circ} \mathrm{C}$ and $\left.75-95 \% \mathrm{RH}\right)$ during the incubation period ( $\mathrm{t}=12$ months).

\subsection{Post-experiment analyses of tile surfaces}

A multi-analytical approach was used to characterize morphological and chemical alterations on the glaze surfaces after 12 months of incubation.

\subsubsection{Quantification of the fungal growth on the glazed tiles}

Photographic records were made with an Olympus C-5060 digital camera every 3 months. The extent of the tile surface area covered by the fungal biofilms was estimated by digital image analysis at the end of the incubation period $(t=12$ months) according to the protocols described by [25-27]. The software packages HyperCube (Army Geospatial Centre, USA) and Image (National Institutes of Health, USA) were used for the image analysis. The surface areas covered by the black biofilms were calculated from the segmentation of the first and third bands obtained by Principal Component Analysis (PC1 and PC3, respectively).

\subsubsection{Optical and scanning electron microscopy}

After 12 months of incubation $(t=12 \mathrm{~m})$, control and colonized pristine and aged tile samples were inspected microscopically for assessing the extent of fungal growth and detecting surface alterations caused by biodeterioration. Observation and documentation were carried out using a Zeiss Axioplan 2 light microscope fitted with a Nikon DMX digital camera.

Scanning electron microscopy (SEM) was also conducted on the tile models after 12 months incubation to assess microbe-substratum interactions. SEM examinations were conducted using a Hitachi 3700N microscope (Hitachi, Tokyo, Japan) interfaced with a Quantax Energy Dispersive X-ray Spectroscopy (EDS) microanalysis system (Bruker AXS GmbH, Karlsruhe, Germany). Variable Pressure-SEM mode was performed for observation of fungal structures with $10 \mathrm{kV}$ accelerating voltage, 
$10 \mathrm{~mm}$ working distance and $30 \mathrm{~Pa}$. The operating conditions for EDS analysis were $20 \mathrm{kV}$ accelerating voltage, $10-12 \mathrm{~mm}$ working distance and $120 \mathrm{~mA}$ emission current.

In addition, the colonized tile samples were observed after cleaning with a cotton swab embedded in a 1:1 water-ethanol solution to assess corrosion patterns, crystalline compounds and leached elements. For comparison purposes, the noninoculated control samples were also analysed. Prior to SEM observations, the tile samples were directly mounted on sample stubs and sputter-coated with gold/palladium.

\subsubsection{Micro-Raman spectroscopy}

Micro-Raman spectroscopy ( $\mu$-Raman) was carried out for characterizing crystals formed on the surface of the glaze using a Labram 300 Jobin Yvon spectrometer, equipped with a He-Ne laser of $17 \mathrm{~mW}$ power operating at $632.8 \mathrm{~nm}$ and also a solid state external laser of $50 \mathrm{~mW}$ power operating at $514.5 \mathrm{~nm}$. Spectra were recorded as an extended scan. The laser beam was focused either with a $10 \times, 50 \times$ or a $100 \times$ Olympus objective lens. The laser power at the surface of the samples varied with the aid of a set of neutral density filters (optical densities $0.3,0.6,1$ and 2). For comparison purposes, spectra of whellite $\left(\mathrm{CaC}_{2} \mathrm{O}_{4} \cdot \mathrm{H}_{2} \mathrm{O}\right)$ (Fluka) were also obtained and analyzed.

\section{Results and discussion}

\subsection{Fungal growth}

The colonization of the glazed tile surfaces by $D$. imbrexigena occurred at a slow rate during the 12 months of the laboratorybased colonization experiment (Fig. 1). This fungus belongs to the Teratosphaeriaceae family, which is characterized by slow growing fungi [28]. This may explain the slow development of $D$. imbrexigena on the tile samples. In fact, this was the criterion for choosing an axenic culture of this fungus as a multi-species culture might result in over-growth by other fungal species rather than the major component of the original biofilm found on the historical tiles from Pena National Palace [8,23]. In addition, the use of a microorganism isolated from a similar substrate is of great relevance to properly evaluate its growth pattern and damaging action on the substrate.

According to visual examination no preferential growth was evident on the pristine and aged tile samples after 12 months of incubation (Fig. 1). The tile surface areas covered by fungi were highly variable within the same type of samples as revealed by digital image analysis. It ranged from 2 to $69 \mathrm{~mm}^{2}$ on the Aged samples and from 2 to $104 \mathrm{~mm}^{2}$ on the Pristine samples (Fig. 2). Although the average coverage area was slightly lower on the aged tiles $\left(22 \pm 19 \mathrm{~mm}^{2}\right)$ than on the pristine tile models $\left(23 \pm 33 \mathrm{~mm}^{2}\right)$, this difference was not statistically significant $(\mathrm{p}>0.05)$.

Therefore, data showed no correlation between the degree of ageing and bioreceptivity for the tested fungus. Similar results were obtained by Rodrigues et al. [15] for stained glass window

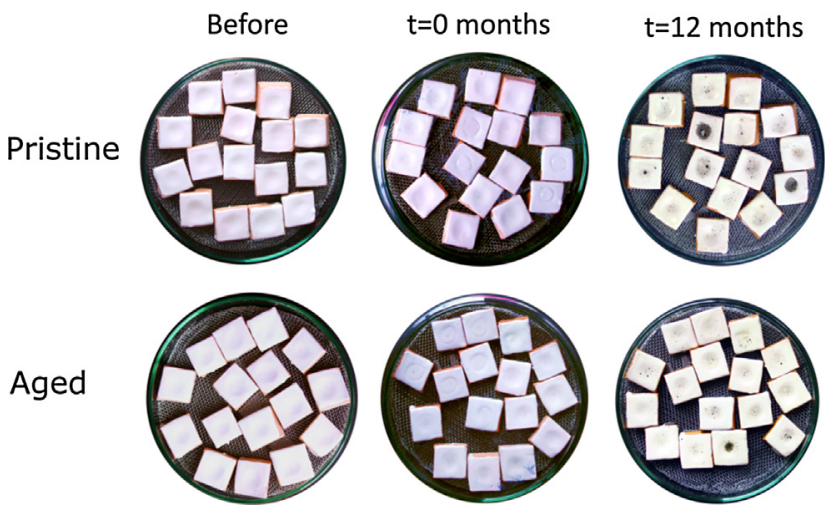

Fig. 1. Petri dishes with pristine and aged tile models, at three different stages: before inoculation (Before), inoculation day $(t=0)$ and after 12 months incubation ( $\mathrm{t}=12$ months). models inoculated with Penicillium sp. and Cladosporium sp. These authors observed no differences in fungal growth between noncorroded and corroded glass surfaces. In contrast, when tile models were inoculated with phototrophic microorganisms a higher bioreceptivity was observed for the aged samples in comparison with the pristine tiles [24].

Several studies have demonstrated that bioreceptivity of inorganic building materials is influenced by the intrinsic material properties, such as surface roughness and porosity [12,29-32]. However, the bioreceptivity of an inorganic substrate to fungi is a complex issue, since heterotrophic microorganisms depend on the availability of external carbon sources. The influence of the composition and physical features of the inorganic substrate might be concealed by the effect of nutrient availability. Research on concrete bioreceptivity showed that nutrient availability was a limiting factor for fungal development on this nutrient-poor substrate [33]. Gadd et al. [34] analysed the nutritional influence on fungal growth and biomass distribution in the presence of toxic metals $(\mathrm{Cu}, \mathrm{Cd}$ and $\mathrm{Zn})$. They concluded that when the amount of available carbon source increased the toxicity of the metals decreased. The assumption that the fungus $D$. imbrexigena, isolated from a complex multispecies biofilm growing over glazed wall tiles [23], was a nutrient poor substrate might not be correct. In natural conditions, cell debris of bacteria, photosynthetic microorganisms and their organic exudates provide carbon sources for fungal growth on inorganic substrates [33]. Consequently, the use of nutritional culture media for laboratory assays might result in higher growth on the surfaces, which in short term experiments can lead to more discernible results $[31,32]$. To understand how the physical properties of the substrate, such as water permeability, surface roughness and chemical composition influence the bioreceptivity to fungi the effect of nutrient availability must be analysed. It might be predictable that the lower the permeability of the substrate the higher the nutrient retention (liquid medium) on the surface. Therefore, the very low permeability and surface roughness of the tile models used in this study (Table 2) suggest that culture medium nutrients were retained on the glazed surface allowing fungal growth throughout the incubation time.

Finally, the quantification of fungal growth was solely based on digital image analysis, which might be limited for detecting differences between pristine $(t=12 \mathrm{~m})$ and aged $(t=12 \mathrm{~m})$ tiles with such reduced and heterogeneous fungal growth. Unlike the methods used for quantifying phototrophic biomass, the fungal-biomass estimation methods are still complex and many of the biomarkers are growth-phase dependent and have a weak correlation with biomass $[35,36]$. Therefore, a more accurate biomass quantitative method should be used, such as real-time quantitative PCR, which has been used to quantify different microbial targets on diverse materials $[37,38]$.

\subsection{Biodeterioration assessment}

\subsubsection{Optical microscopy and SEM observations}

Pristine and aged glazed tiles were examined by optical microscopy after the 12-month incubation period to assess surface morphology and detect corrosion products. On the non-inoculated control samples, crystals with different sizes were observed over the glazed surface (Fig. 3a, b). Lower magnified images showed the differences between fissure network of the pristine and aged samples (Fig. 3a b). This comprises the main distinguishing feature between the two types of samples and justifies the increase of permeability caused by the artificial ageing (Table 2). Regarding the inoculated samples, dark fungal colonies could be observed over the surface and white crystals were formed close to fungal structures (Fig. $3 c$ and d). The development of fungi over the glazed tile 


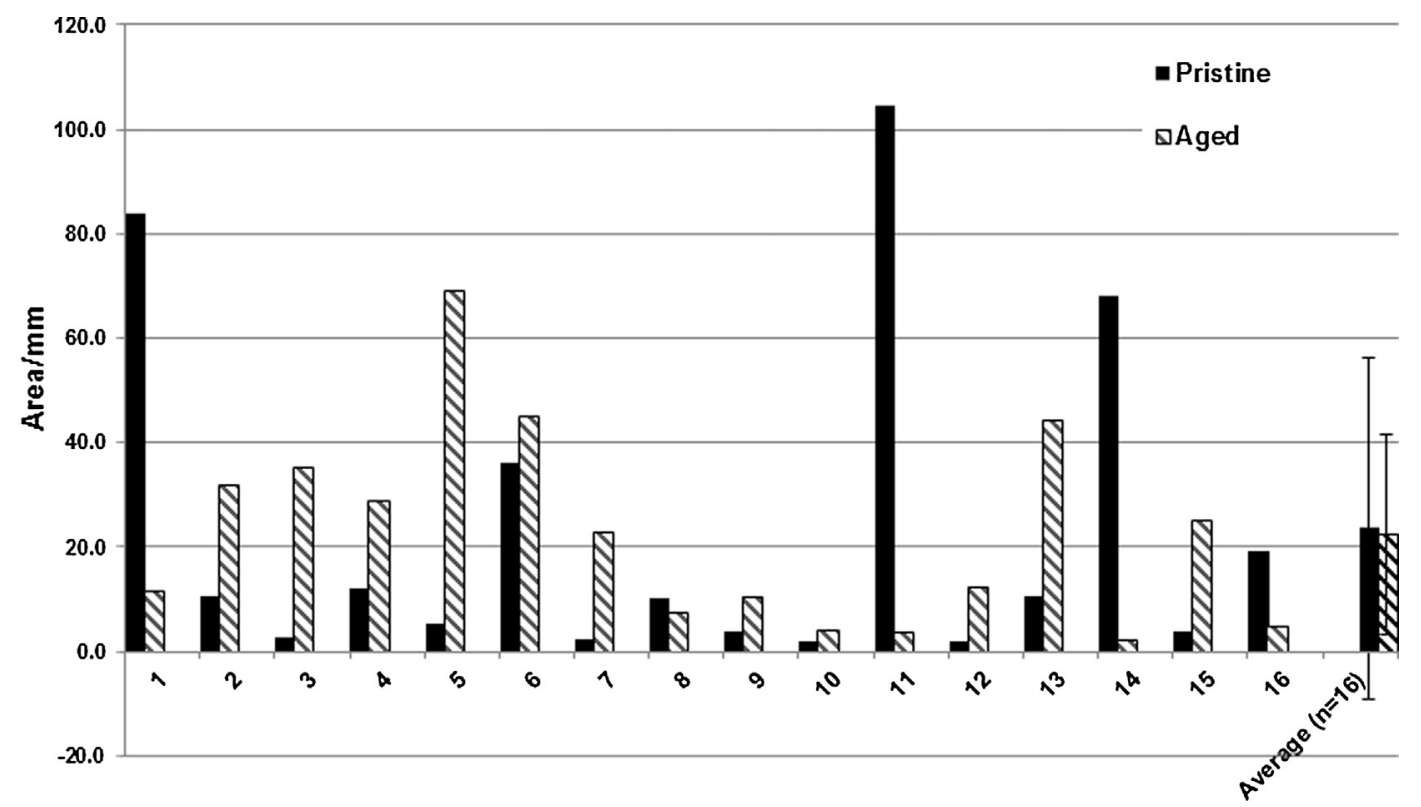

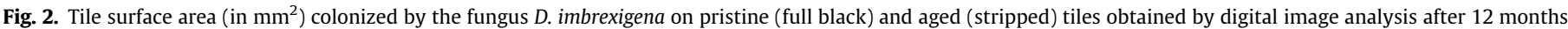
incubation. Last column shows the average value $(n=16)$ and standard deviation $( \pm S D)$.
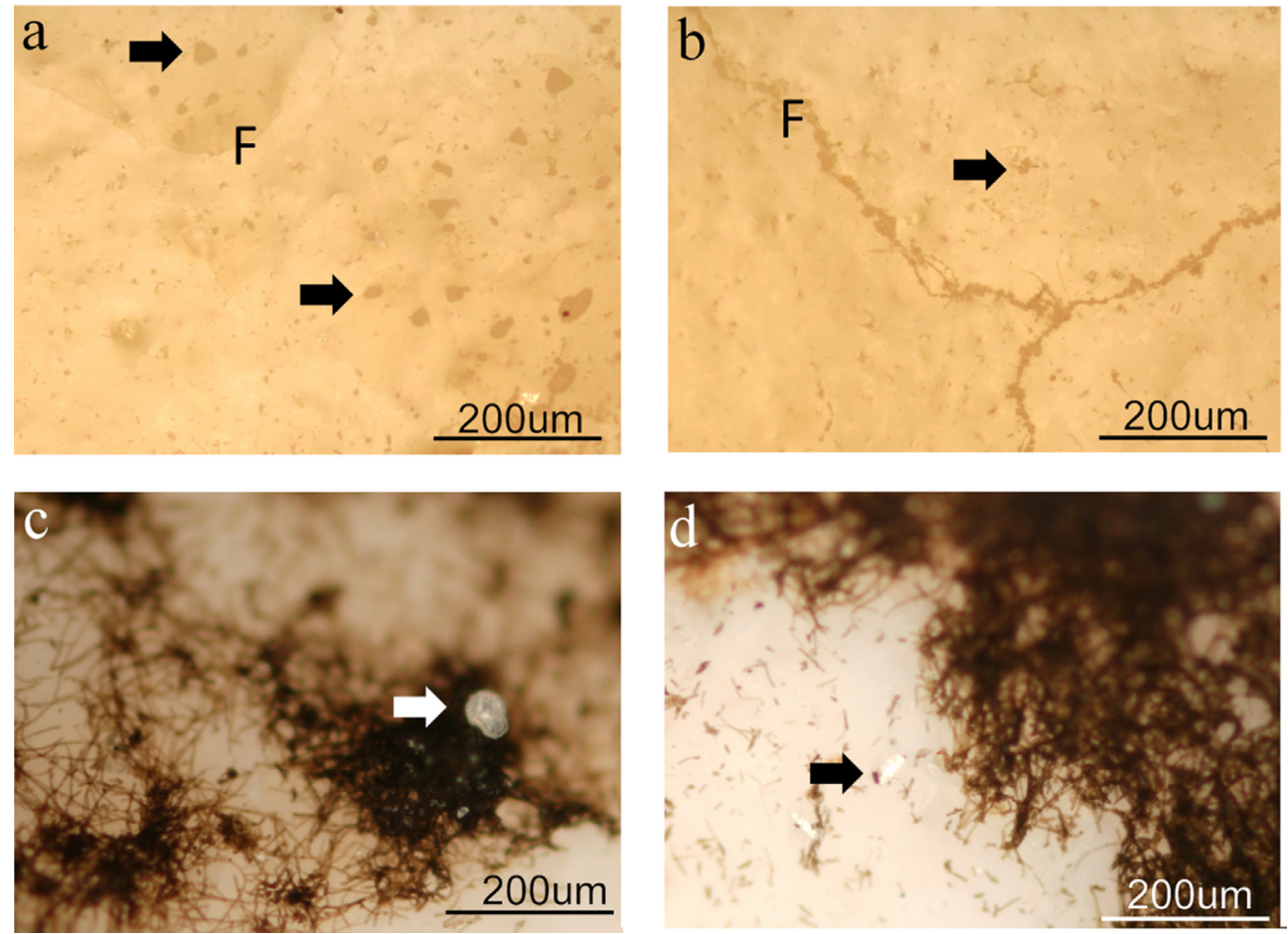

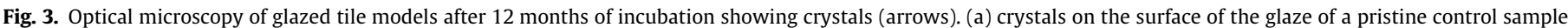

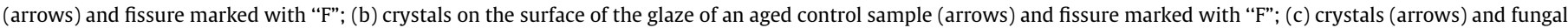
colonies on the surface of the glaze of a pristine sample; and (d) crystals (arrows) and fungal colonies on the surface of the glaze of an aged sample.

occurred mainly epilithically, as no chasmolithic nor cryptoendolithic growth could be observed on the tiles (Fig. 3).

SEM observations allowed higher resolution and greater depth of focus of the glazed tile surface of the non-inoculated control pristine and aged samples (Fig. 4). The surface of pristine control (Fig. 4a) and aged control (Fig. 4b) samples showed the heterogeneous distribution of crystals over the glassy surface. Higher magnified SEM images revealed the crystal morphology on both pristine and aged control samples with irregular and rhombohedral-like shaped crystals (Fig. 4c, d). The EDS microanalysis allowed their elemental characterization as calcium-rich crystals (Fig. 4e, f).

SEM analysis of the inoculated glazed tile models after 12 months incubation time also showed crystal formation on the glazed surfaces. These crystals were intertwined by fungal hyphae and covered by a mucilaginous matrix, probably extracellular polymeric substances (EPS) (Fig. 5a, b). The EDS microanalysis of the crystals revealed high concentration of $\mathrm{Ca}$ and $\mathrm{C}$ (Fig. $5 c, d$ ). On 

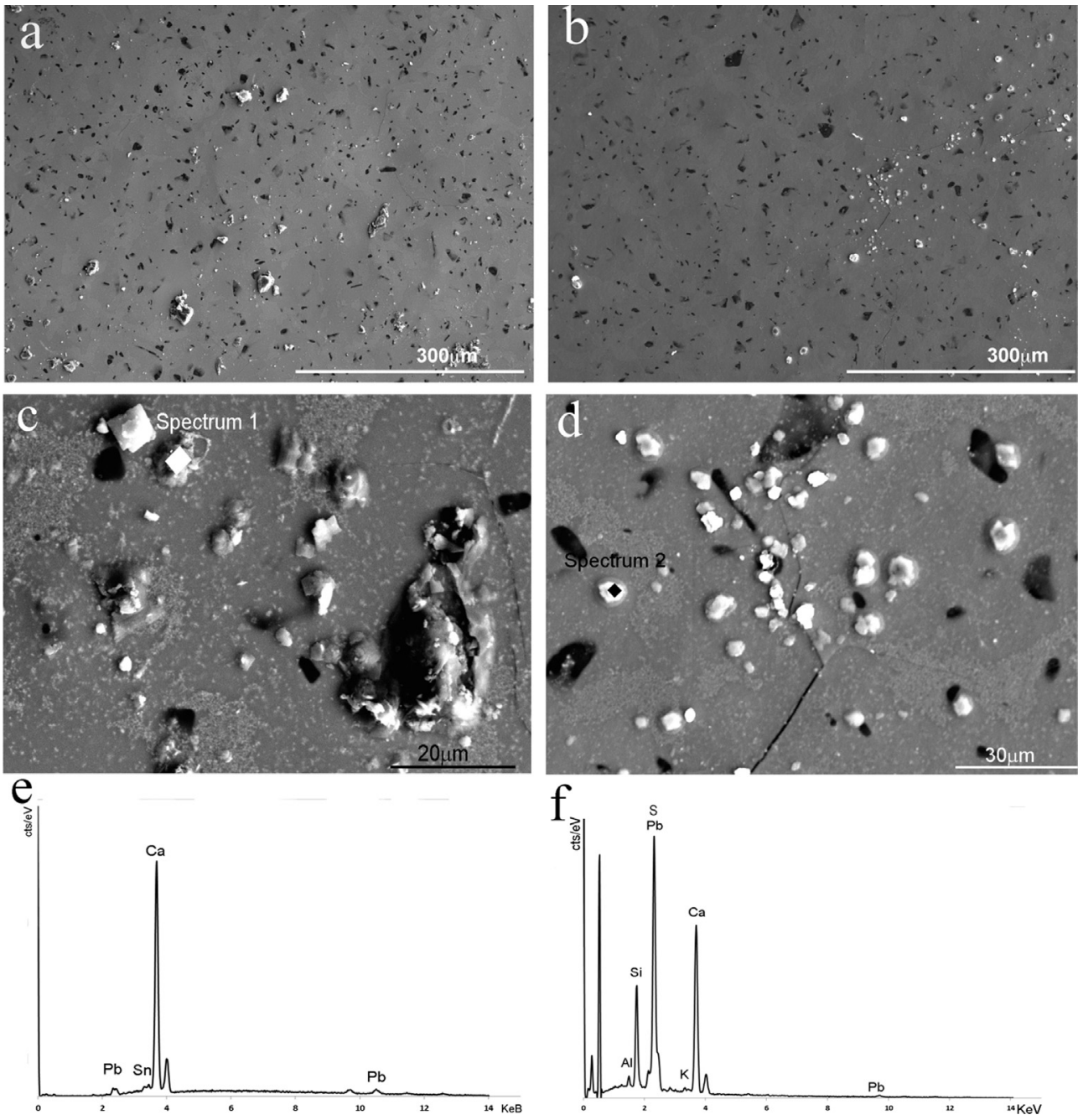

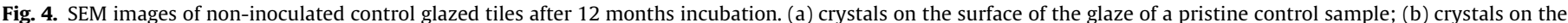

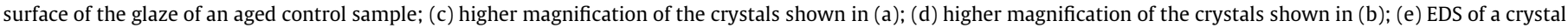
indicated as spectrum 1 in (c); and (f) EDS of a crystal indicated as spectrum 2 in (d)

the inoculated samples, larger crystals and also smaller crystals very close to the fungal hyphae could be observed (Fig. 5a, c). After removal of the biofilm, neither cell imprints nor penetration of $D$. imbrexigena hyphae into tile fissures were detected on pristine (Fig. 5e) or aged (Fig. 5f) glazed tile samples.

The composition of the crystals formed over the surface of the incubated glazed tiles indicate mobilization of calcium on both non-inoculated control samples and inoculated samples. Nevertheless, the morphology of the crystals formed in the presence of microorganisms was different from the non-inoculated control samples.

\subsection{2. $\mu$-Raman}

Table 3 summarizes the main compounds identified on the surface of the samples. All samples revealed calcium carbonate crystals (probably calcite) over the glaze, which could be identified by the Raman spectra with bands at 156, 286, 712 and $1088 \mathrm{~cm}^{-1}$ [39]. Calcium sulphate (probably gypsum) was also present on the samples with most intense bands at 412, 494 and $1008 \mathrm{~cm}^{-1}$ [39]. Carbonates and sulphates have been identified as common corrosion products of silicate glass and also of claybased ceramic bodies [15,40,41].

These compounds were also identified on the tile models inoculated with a phototrophic mixed culture in a previous work [24].
In general, more crystals were observed on the inoculated samples compared to the control samples. Similar results were reported in other laboratory-based experiments, in which higher amount of crystals were detected on inoculated stained glass reproductions [15].

Regarding the inoculated pristine and aged tiles besides calcite and gypsum, some irregular shaped crystals assigned to oxalates were detected (Table 3 and Fig. 6).

These oxalates may have a biological origin since they were not found on the control samples. Raman spectrum obtained from a crystal on a pristine $(t=12 \mathrm{~m})$ sample showed characteristic bands at $161,185,429,910$ and $1476 \mathrm{~cm}^{-1}$ (Fig. 6(i)), similar to the banding pattern described for weddellite [42]. Similar crystals were detected on the aged $(\mathrm{t}=12 \mathrm{~m})$ glazes (Fig. 6(iii)), showing only a slight shift from the previously described bands. In the same sample, one spectrum was collected with bands at 161, 187, 638, 846, 1463 and $1489 \mathrm{~cm}^{-1}$ that could be assigned to whewellite [42]. Oxalates have been considered biosignatures valuable for astrobiology as they were found in extreme environments, such as cultural heritage assets [43-46]. These metabolite compounds have a crucial role in many metal and mineral transformations intermediated by fungi $[43,47]$. In fact, the formation of calcium oxalate has been previously associated with the biochemical deterioration of the ceramic body by fungi and lichens, through the precipitation 

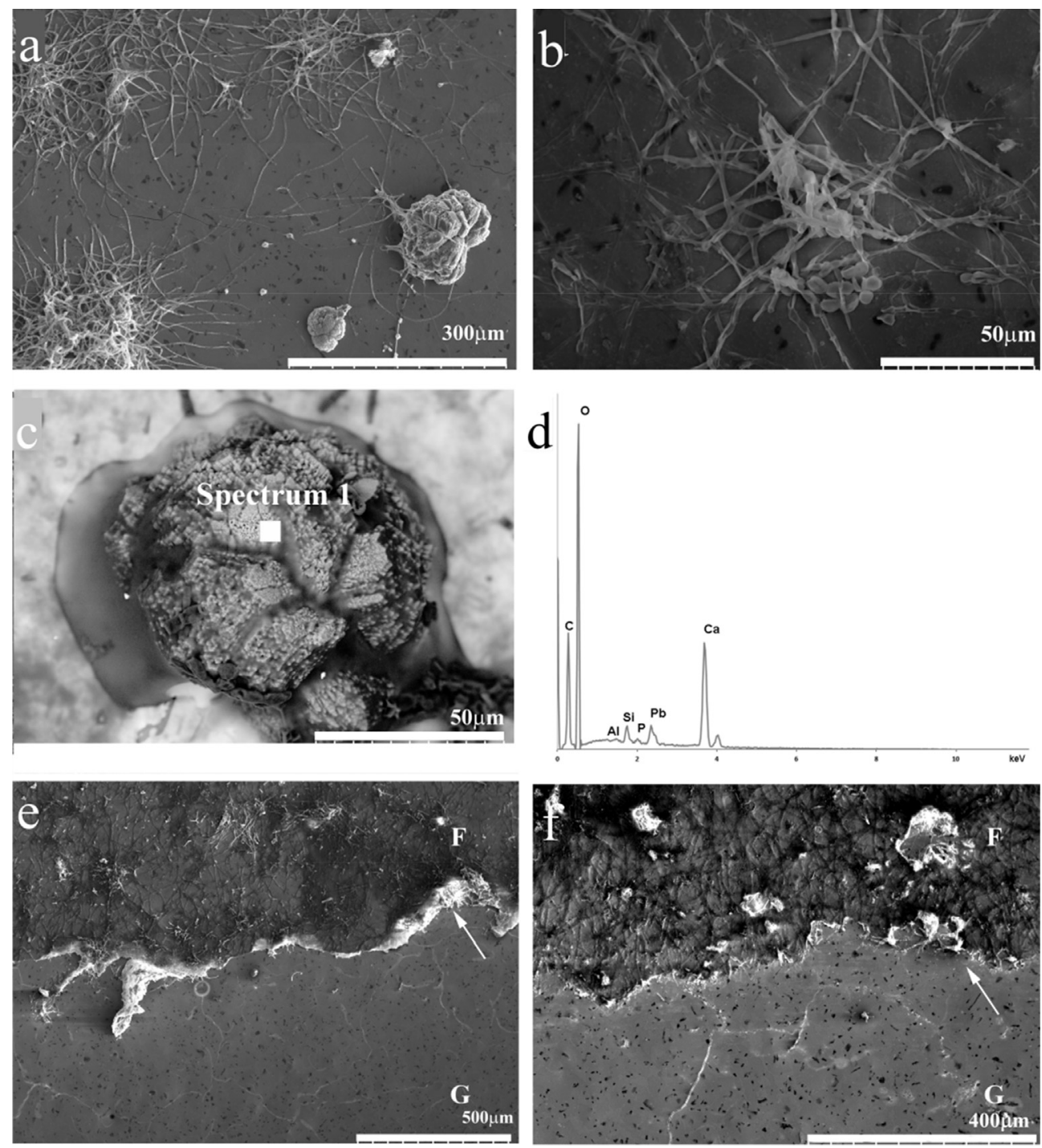

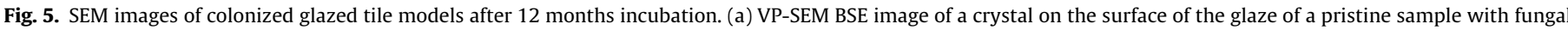

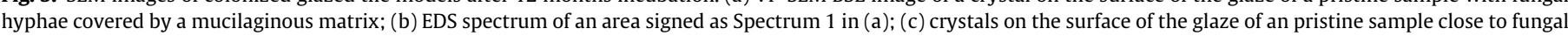

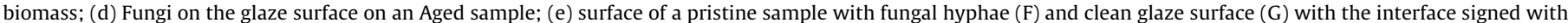

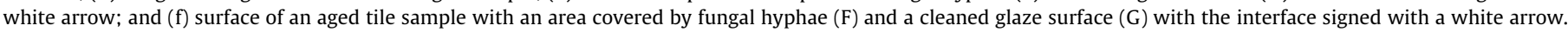

Table 3

Crystalline substances found over the glaze samples after 12 months incubation, identified by $\mu$-Raman.

\begin{tabular}{llll}
\hline Tile samples & Calcite $\left(\mathrm{CaCO}_{3}\right)$ & Gypsum $\left(\mathrm{CaSO}_{4}\right)$ & Oxalates \\
\hline Colonized pristine & $*$ & $*$ & $*$ \\
Colonized aged & $*$ & $*$ & $*$ \\
Pristine control & $*$ & $*$ & \\
Aged control & $*$ & & \\
\hline
\end{tabular}

of this compound in the ceramic matrix [48-50]. Oxalic acid is used in industry for the sequestration of metal cations [51,52]. Yet, we could not detect the formation of any lead or tin oxalates on the samples, which could be expected due to high concentration of lead and tin of the glaze. Other studies have shown that some fungi can grow even in the presence of the most toxic chemical elements, such as $\mathrm{Pb}, \mathrm{Cd}, \mathrm{Sn}$ and $\mathrm{Cu}$ by producing several oxalates and acidic compounds that will easily chelate ions from insoluble complexes $[43,51,53,54]$.
Although calcium oxalate formation has been considered protective in stone conservation [55], the precipitation of compounds over glazes alters their gloss and reflectance [56]. Optical features such as gloss and reflectance are aesthetical characterizing features of glazed tiles $[1,56]$, therefore the formation of calcium oxalates over the glaze has a detrimental effect on historical glazed tiles.

This experiment provided relevant results regarding the effect of the fungi in glazed tile biodeterioration, such as in chemical biodeterioration due to the formation of calcium oxalate compounds. In addition, this laboratory-based tile biodeterioration experiment provided information regarding the growth pattern of the fungus $D$. imbrexigena, which was less invasive than phototrophic microorganisms as revealed in a previous study [24].

\section{Conclusions}

The laboratory-based biodeterioration experiment performed in this work allowed studying the growth of fungi over the glazed tile models with two different ageing degrees and observing the main alterations caused by their growth on the glaze surface. No signif- 


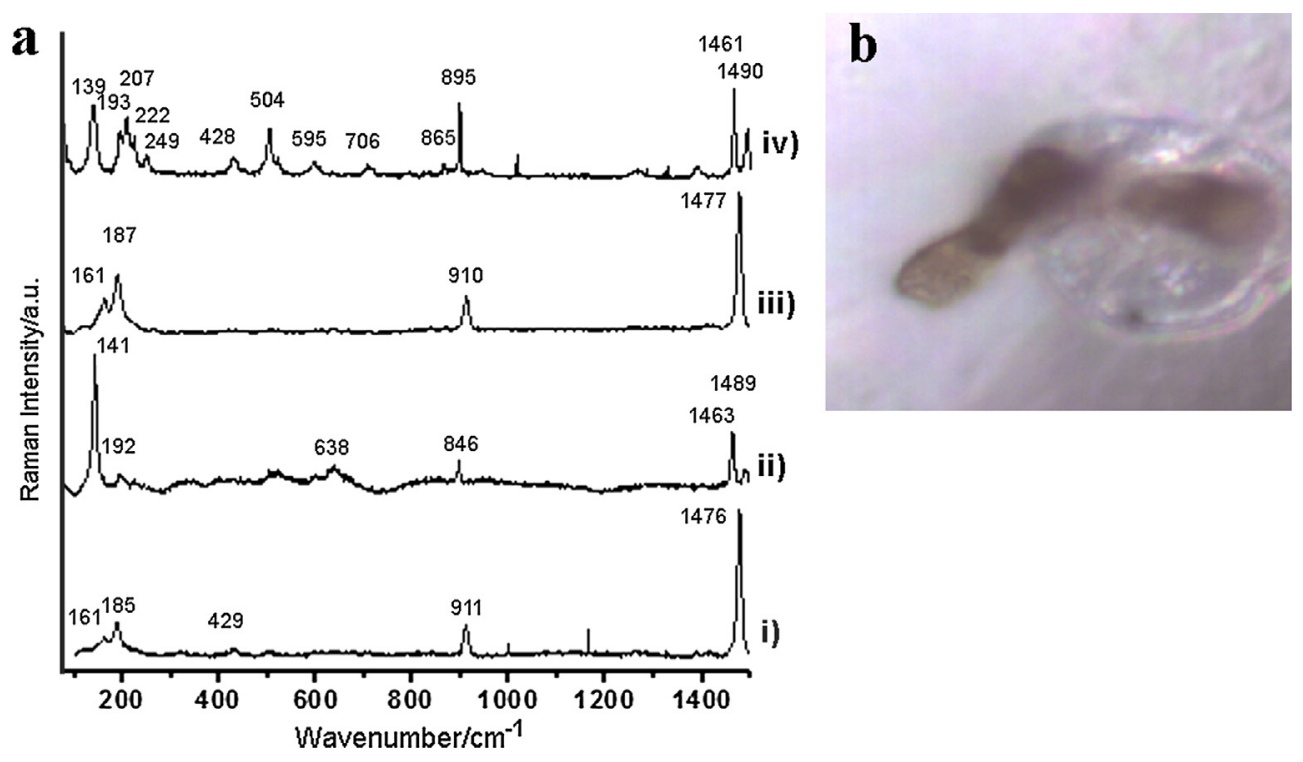

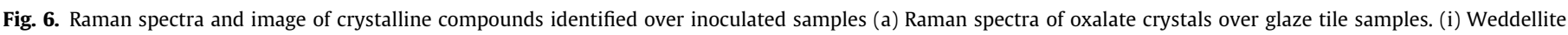

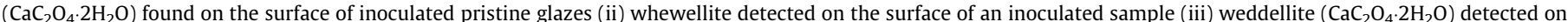

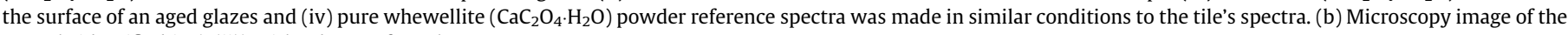
crystals identified in (a(ii)) with a brown fungal structure.

icant differences were detected regarding the bioreceptivity of the pristine and aged samples. Consequently, the ageing degree of the glazed tiles could not be related to fungal growth rate.

The results obtained in this experiment indicated that Devriesia imbrexigena was able to mobilize elements present on the glazed tiles and form oxalates. Calcium oxalate crystals were deposited over the inoculated glazed tile models after the 12 months of incubation. For the identification of these compounds, $\mu$-Raman proved to be a useful tool in the investigation of biogenic compounds produced by fungi.

\section{Conflict of interest}

I declare there is no conflict of interests in this research.

\section{Acknowledgements}

This work was supported by the Portuguese Foundation for Science and Technology (FCT) [grant SFRH/BD/46038/2008; project UID/EAT/00729/2013]. A.Z. Miller thanks the Spanish Ministry of Economy, Industry and Competitiveness for the "Juan de la Cierva - Incorporación" post-doctoral contract [IJCI-2014-20443]. Alan JL Phillips acknowledges the support from Biosystems and Integrative Sciences Institute (BioISI, FCT/UID/Multi/04046/2013).

\section{References}

[1] C. Lobo, J. Pernão, Glazed tiles as an improving element for environmental quality in Urban Landscape, Colour Des. Creat. 9 (2010) 1-12.

[2] L. Durbin, Architectural Tiles: Conservation and Restoration: From the Medieval Period to the Twentieth Century, Butterwort, Boston, 2005.

[3] H. Hueck, The biodeterioration of materials as part of hylobiology, Mater. Org. 1 (1965) 5-34.

[4] M.L. Coutinho, A.Z. Miller, M.F. Macedo, Biological colonization and biodeterioration of architectural ceramic materials: an overview, J. Cult. Herit. 16 (2015) 759-777, https://doi.org/10.1016/j.culher.2015.01.006.

[5] L. Giacomucci, R. Bertoncello, O. Salvadori, I. Martini, M. Favaro, F. Villa, C. Sorlini, F. Cappitelli, Microbial deterioration of artistic tiles from the façade of the Grande Albergo Ausonia \& Hungaria (Venice, Italy), Microb. Ecol. 62 (2011) 287-298, https://doi.org/10.1007/s00248-011-9812-0.

[6] M.L. Coutinho, A.Z. Miller, P.M. Martin-Sanchez, J. Mirão, A. Gomez-Bolea, B. Machado-Moreira, L. Cerqueira-Alves, V. Jurado, C. Saiz-Jimenez, A. Lima, A.J.L. Phillips, F. Pina, M.F. Macedo, A multiproxy approach to evaluate biocidal treatments on biodeteriorated majolica glazed tiles, Environ. Microbiol. 18 (2016) 4794-4816, https://doi.org/10.1111/1462-2920.13380.

[7] M.L. Coutinho, C. Pinheiro, A. Phillips, M. Macedo, Biodeterioration of Tiles from Pena National Palace (Portugal). First Step: Identification of Fungal Community, Prepr. ICOM-CCs 16th Trienn. Conf. Int. Counc. Museums, 2011, p. 82. http://www.criterio.biz/icom-cc-preprints-2011/ (accessed October 7, 2013).

[8] M.L. Coutinho, A.Z. Miller, S. Gutierrez-Patricio, M. Hernandez-Marine, A Gomez-Bolea, M.A. Rogerio-Candelera, A.J.L. Philips, V. Jurado, C. Saiz-Jimenez, M.F. Macedo, Microbial communities on deteriorated artistic tiles from Pena National Palace (Sintra, Portugal), Int. Biodeterior. Biodegrad. 84 (2013) 322332, https://doi.org/10.1016/j.ibiod.2012.05.028.

[9] K. Sterflinger, Fungi: their role in deterioration of cultural heritage, Fungal Biol. Rev. 24 (2010) 47-55, https://doi.org/10.1016/j.fbr.2010.03.003.

[10] M.M. Oliveira, T.B.C. Sanjad, C.J.P. Bastos, Biological degradation of glazed ceramic tiles, in: P.B. Lourenço, P. Roca (Eds.), Hist. Constr., Guimarães, 2001: pp. 337-342. http://www.csarmento.uminho.pt/docs/ncr/ historical_constructions/page337-342_17_pdf (accessed August 27, 2014).

[11] N. Pedi, E. Conceição, M.J. Fernandes, D. Massa, E. Nogeira, P. Ribeiro, J.H. Arcoverde, S. Lemos, A. Marsden, R. Neves, Fungos isolados em azulejos do convento de Santo António, Recife, Pernambuco, IX Jorn. Ensino, Pesqui. e Extensão. (2009). http://www.eventosufrpe.com.br/jepex2009/cd/resumos/ R0550-1.pdf (accessed January 18, 2013).

[12] A.Z. Miller, P. Sanmartín, L. Pereira-Pardo, A. Dionísio, C. Saiz-Jimenez, M. F.F. Macedo, B. Prieto, Bioreceptivity of building stones: a review, Sci. Total Environ. 426 (2012) 1-12, https://doi.org/10.1016/j.scitotenv. 2012.03.026.

[13] F. De Leo, G. Campanella, E. Proverbio, C. Urzì, Laboratory tests of fungal biocorrosion of unbonded lubricated post-tensioned tendons, Constr. Build. Mater. 49 (2013) 821-827, https://doi.org/10.1016/j.conbuildmat.2013.08.071.

[14] A.A. Gorbushina, K.A. Palinska, Biodeteriorative processes on glass: experimental proof of the role of fungi and cyanobacteria (1999) 183-191.

[15] A. Rodrigues, S. Gutierrez-Patricio, A.Z. Miller, C. Saiz-Jimenez, R. Wiley, D. Nunes, M. Vilarigues, M.F. Macedo, Fungal biodeterioration of stained-glass windows, Int. Biodeterior. Biodegrad. 90 (2014) 152-160, https://doi.org/ 10.1016/j.ibiod.2014.03.007.

[16] M. Radeka, Z. Bačkalić, M. Vrebalov, The effect of firing temperature of clay roofing tiles on the mechanisms of frost action, Ind. Ceram. 20 (2008) 97-104 (accessed November 4, 2014) http://scindeks.ceon.rs/article.aspx?artid=035054210807182R

[17] M. Radeka, J. Kiurski, S. Markov, R. Marinković-Nedučin, J. Ranogajec, Microbial deterioration of clay roofing tiles, in: C.A. Brebbia (Ed.), Struct. Stud. Repairs Maint. Herit. Archit. XMaintenance Herit. Archit. X, WIT Press, Southampton, UK, 2007, pp. 567-575, https://doi.org/10.2495/STR070531.

[18] N. Carmona, L. Laiz, J.M. Gonzalez, M. Garcia-Heras, M.A. Villegas, C. SaizJimenez, Biodeterioration of historic stained glasses from the Cartuja de Miraflores (Spain), Int. Biodeterior. Biodegrad. 58 (2006) 155-161, https://doi. org/10.1016/j.ibiod.2006.06.014.

[19] S. Rolleke, Methods analysis of bacterial communities on historical glass by denaturing gradient gel electrophoresis of PCR-amplified gene fragments coding for 16S rRNA, 36 (1999) 107-114. 
[20] C. Schabereiter-Gurtner, G. Piñar, W. Lubitz, S. Rölleke, An advanced molecular strategy to identify bacterial communities on art objects, J. Microbiol. Methods 45 (2001) 77-87. http://www.ncbi.nlm.nih.gov/pubmed/11311392.

[21] M. Bartosik, Z. Zakowska, K. Cedzińska, K. Rozniakowski, Biodeterioration of optical glass induced by lubricants used in optical instruments technology, Pol. J. Microbiol. 59 (2010) 295-300. http://www.ncbi.nlm.nih.gov/pubmed/ 21466048.

[22] M.A. Shirakawa, V.M. John, A. Mocelin, R. Zilles, S.H. Toma, K. Araki, H.E. Toma A.C. Thomaz, C.C. Gaylarde, Effect of silver nanoparticle and $\mathrm{TiO}_{2}$ coatings on biofilm formation on four types of modern glass, Int. Biodeterior. Biodegrad. 108 (2016) 175-180, https://doi.org/10.1016/j.ibiod.2015.12.025.

[23] P.W. Crous, R.G. Shivas, M.J. Wingfield, B.A. Summerell, A.Y. Rossman, J.L. Alves, G.C. Adams, R.W. Barreto, A. Bell, M.L. Coutinho, S.L. Flory, G. Gates, K.R. Grice, G.E.St.J. Hardy, N.M. Kleczewski, L. Lombard, C.M.O. Longa, G. LouisSeize, F. Macedo, D.P. Mahoney, G. Maresi, P.M. Martin-Sanchez, L. Marvanová, A.M. Minnis, L.N. Morgado, M.E. Noordeloos, A.J.L. Phillips, W. Quaedvlieg, P.G. Ryan, C. Saiz-Jimenez, K.A. Seifert, W.J. Swart, Y.P. Tan, J.B. Tanney, P.Q. Thu, S.I. R. Videira, D.M. Walker, J.Z. Groenewald, Fungal Planet description sheets: 128-153, Persoonia 29 (2012) 146-201, https://doi.org/10.3767/ $003158512 X 661589$.

[24] M.L. Coutinho, A.Z. Miller, M.A. Rogerio-Candelera, J. Mirão, L. Cerqueira Alves, J.P. Veiga, H. Águas, S. Pereira, A. Lyubchyk, M.F. Macedo, An integrated approach for assessing the bioreceptivity of glazed tiles to phototrophic microorganisms, Biofouling 32 (2016) 243-259, https://doi.org/10.1080/ 08927014.2015.1135242.

[25] A.Z. Miller, M.Á. Rogerio-candelera, M.F. Macedo, C. Saiz, Microalgae as biodeteriogens of stone cultural heritage: qualitative and quantitative research by non-contact techniques, Microalgae Biotechnol. Microbiol. Energy (2011) 345-358. http://hdl.handle.net/10261/56993 (accessed May 16, 2018).

[26] A.Z. Miller, M.A. Rogerio-Candelera, L. Laiz, J. Wierzchos, C. Ascaso, M.A. Sequeira-Braga, M. Hernández-Mariné, A. Maurício, A. Dionisio, M.F.F. Macedo, C. Saiz-Jimenez, M.A. Sequeira Braga, M. Hernández-Mariné, A. Maurício, A. Dionísio, M.F. Macedo, C. Saiz-Jimenez, Laboratory-induced endolithic growth in calcarenites: biodeteriorating potential assessment, Microb. Ecol. 60 (2010) 55-68, https://doi.org/10.1007/s00248-010-9666-x.

[27] M.A. Rogerio-Candelera, V. Jurado, L. Laiz, C. Saiz-Jimenez, Laboratory and in situ assays of digital image analysis based protocols for biodeteriorated rock and mural paintings recording, J. Archaeol. Sci. 38 (2011) 2571-2578, https:// doi.org/10.1016/j.jas.2011.04.020.

[28] E. Egidi, G.S. Hoog, D. Isola, S. Onofri, W. Quaedvlieg, M. Vries, G.J.M. Verkley, J. B. Stielow, L. Zucconi, L. Selbmann, Phylogeny and taxonomy of meristematic rock-inhabiting black fungi in the Dothideomycetes based on multi-locus phylogenies, Fungal Divers. 65 (2014) 127-165, https://doi.org/10.1007/ s13225-013-0277-y.

[29] M. D’Orazio, G. Cursio, L. Graziani, L. Aquilanti, A. Osimani, F. Clementi, C. Yéprémian, V. Lariccia, S. Amoroso, Effects of water absorption and surface roughness on the bioreceptivity of ETICS compared to clay bricks, Build. Environ. 77 (2014) 20-28, https://doi.org/10.1016/j.buildenv.2014.03.018.

[30] M. Korkanc, A. Savran, Impact of the surface roughness of stones used in historical buildings on biodeterioration, Constr. Build. Mater. 80 (2015) 279294, https://doi.org/10.1016/J.CONBUILDMAT.2015.01.073.

[31] M.F. Gazulla, E. Sánchez, J.M. González, M.C. Portillo, M. Orduña, Relationship between certain ceramic roofing tile characteristics and biodeterioration, J. Eur. Ceram. Soc. 31 (2011) 2753-2761, https://doi.org/10.1016/ j.jeurceramsoc.2011.07.023

[32] V. Ferrándiz-Mas, T. Bond, Z. Zhang, J. Melchiorri, C.R. Cheeseman, Optimising the bioreceptivity of porous glass tiles based on colonization by the alga Chlorella vulgaris, Sci. Total Environ. 563-564 (2016) 71-80, https://doi.org/ 10.1016/j.scitotenv.2016.04.023.

[33] D.J. Giannantonio, J.C. Kurth, K.E. Kurtis, P.A. Sobecky, Effects of concrete properties and nutrients on fungal colonization and fouling, Int. Biodeterior. Biodegrad. 63 (2009) 252-259, https://doi.org/10.1016/j.ibiod.2008.10.002.

[34] G.M. Gadd, L. Ramsay, J.W. Crawford, K. Ritz, Nutritional influence on fungal colony growth and biomass distribution in response to toxic metals, FEMS Microbiol. Lett. 204 (2001) 311-316, https://doi.org/10.1016/S0378-1097(01) 00399-8.

[35] M. Miller, A. Palojärvi, A. Rangger, M. Reeslev, A. Kjøller, A. Paloja, The use of fluorogenic substrates to measure fungal presence and activity in soil the use of fluorogenic substrates to measure fungal presence and activity in soil, 64 (1998).

[36] K. Suberkropp, M.O. Gessner, E. Chauvet, Comparison of ATP and ergosterol as indicators of fungal biomass associated with decomposing leaves in streams,
Appl. Environ. Microbiol. 59 (1993) 3367-3372. http://www.pubmedcentral. nih.gov/articlerender.fcgi?artid=182460\&tool=pmcentrez\&rendertype $=$ abstract.

[37] P.M. Martin-Sanchez, F. Bastian, C. Alabouvette, C. Saiz-Jimenez, Real-time PCR detection of Ochroconis lascauxensis involved in the formation of black stains in the Lascaux Cave, France, Sci. Total Environ. 443 (2013) 478-484, https:/ doi.org/10.1016/j.scitotenv.2012.11.026.

38] P.M. Martin-Sanchez, C. Gebhardt, J. Toepel, J. Barry, N. Munzke, J. Günster, A.A Gorbushina, Monitoring microbial soiling in photovoltaic systems: a qPCRbased approach, Int. Biodeterior. Biodegrad. 129 (2018), https://doi.org/ 10.1016/j.ibiod.2017.12.008.

[39] M. Maguregui, A. Sarmiento, R. Escribano, I. Martinez-Arkarazo, K. Castro, J.M. Madariaga, Raman spectroscopy after accelerated ageing tests to assess the origin of some decayed products found in real historical bricks affected by urban polluted atmospheres, Anal. Bioanal. Chem. 395 (2009) 2119-2129, https://doi.org/10.1007/s00216-009-3153-6.

[40] B. Fabbri, S. Gualtieri, S. Shoval, The presence of calcite in archeological ceramics, J. Eur. Ceram. Soc. 34 (2014) 1899-1911, https://doi.org/10.1016 j.jeurceramsoc.2014.01.007.

[41] M. Vilarigues, P. Redol, A. MacHado, P.A. Rodrigues, L.C. Alves, R.C. Da Silva Corrosion of 15 th and early 16 th century stained glass from the monastery of Batalha studied with external ion beam, Mater. Charact. 62 (2011) 211-217. https://doi.org/10.1016/j.matchar.2010.12.001.

[42] R.L. Frost, Raman spectroscopy of natural oxalates, Anal. Chim. Acta 517 (2004) 207-214, https://doi.org/10.1016/j.aca.2004.04.036.

[43] G.M. Gadd, J. Bahri-Esfahani, O Li, YJ. Rhee, Z. Wei, M. Fomina, X. Liang Oxalate production by fungi: significance in geomycology, biodeterioration and bioremediation, Fungal Biol. Rev. 28 (2014) 36-55, https://doi.org/ 10.1016/j.fbr.2014.05.001.

[44] A.A. Gorbushina, W.E. Krumbein, M. Volkmann, Rock surfaces as life indicators: new ways to demonstrate life and traces of former life, Astrobiology 2 (2002) 203-213, https://doi.org/10.1089/15311070260192273.

[45] R.L. Frost, Y. Jing, Z Ding Raman and FTIR spectroscopy of natural oxalates: Implications for the evidence of life on Mars, Chin. Sci. Bull. 48 (2003) 1844 https://doi.org/10.1360/03wd0145.

[46] T. Rosado, M. Gil, J. Mirão, A. Candeias, A.T. Caldeira, Oxalate biofilm formation in mural paintings due to microorganisms - a comprehensive study, Int Biodeterior. Biodegrad. 85 (2013) 1-7, https://doi.org/10.1016/j. ibiod.2013.06.013.

[47] S.O. Lee, T. Tran, Y.Y. Park, S.J. Kim, M.J. Kim, Study on the kinetics of iron oxide leaching by oxalic acid, Int. J. Miner. Process. 80 (2006) 144-152, https://doi. org/10.1016/j.minpro.2006.03.012.

[48] J. Ranogajec, S. Markov, J. Kiurski, M. Radeka, V. Ducman, Microbia deterioration of clay roofing tiles as a function of the firing temperature, J. Am. Ceram. Soc. 91 (2008) 3762-3767, https://doi.org/10.1111/j.15512916.2008.02691.x.

[49] M. Radeka, J. Ranogajec, J. Kiurski, S. Markov, R. Marinković-Nedučin, Influence of lichen biocorrosion on the quality of ceramic roofing tiles, J. Eur. Ceram. Soc. 27 (2007) 1763-1766, https://doi.org/10.1016/j.jeurceramsoc.2006.05.001.

[50] J.G. Ranogajec, J.S. Kiurski, A.L. Ujhelji, M.M. Radeka, M.T. Bokorov, J. Balint, A Borbelj-Mesaros, Biochemical corrosion of ceramic roofing tiles by lichen actions, Interceram 54 (2005) 340-343. http://cat.inist.fr/?aModele= afficheN\&cpsidt=17126132.

[51] M. Fomina, S. Hillier, J.M. Charnock, K. Melville, G.M. Gadd, I.J. Alexander, Role of oxalic acid overexcretion in transformations of toxic metal minerals by Beauveria caledonica, (2005). doi: 10.1128/AEM.71.1.371.

[52] A. Wladimirsky, D. Palacios, M.C. D’Antonio, A.C. González-Baró, E.J. Baran, Vibrational spectra of tin(II) oxalate, Spectrochim. Acta A, Mol. Biomol. Spectrosc. 77 (2010) 334-335, https://doi.org/10.1016/j.saa.2010.04.037.

[53] J.A. Sayer, J.D. Cotter-Howells, C. Watson, S. Hillier, G.M. Gadd, Lead mineral transformation by fungi, Curr. Biol. 9 (1999) 691-694. http://www.ncbi.nlm. nih.gov/pubmed/10395543.

[54] J.A. Sayer, S.L. Raggett, G.M. Gadd, Solubilization of insoluble metal compounds by soil fungi: development of a screening method for solubilizing ability and metal tolerance, Mycol. Res. 99 (1995) 987-993, https://doi.org/10.1016 S0953-7562(09)80762-4.

[55] B. Doherty, M. Pamplona, C. Miliani, M. Matteini, A. Sgamellotti, B. Brunetti, Durability of the artificial calcium oxalate protective on two Florentine monuments, J. Cult. Herit. 8 (2007) 186-192, https://doi.org/10.1016/j. culher.2006.12.002.

[56] M. Vendrell-Saz, Ceramica aplicada en la arquitectura, in: A. Balderrama, A.A Vidal, I.B. Cardiel (Eds.), El Estudio y La Conservation de la Cerámica Decorada en Arquitectura, ICCROM, Rome, 2003, pp. 10-14. 